A C T A U N I V E R S I T A T I S N I C O L A I C O P E R N I C I
\begin{tabular}{lr} 
DOI: http://dx.doi.org/10.12775/AUNC_ZARZ.2016.002 & ZARZĄDZANIE XLIII - NR 1 (2016) \\
\hline $\begin{array}{l}\text { Pierwsza wersja złożona 15.12.2015 } \\
\text { Ostatnia wersja zaakceptowana 22.01.2016 }\end{array}$ & ISSN (print) 1689-8966 (online) 2450-7040
\end{tabular}

Dawid Szostek*

\title{
PRACOHOLIZM W AKTYWNOŚCI TWÓRCZEJ CZŁOWIEKA NA PRZYKŁADZIE PRACOWNIKÓW NAUKI
}

Z a r y s t r e ś c i: Artykuł traktuje o zjawisku pracoholizmu wśród osób zajmujących się działalnością twórczą (w tym naukową). Celem podjętym w artykule jest opisanie zjawiska pracoholizmu wśród osób, które zajmują się aktywnością twórczą. W pierwszej części zdefiniowano aktywność twórczą, a następie opisano przyczyny, przejawy i skutki pracoholizmu. W kolejnej części zaprezentowano najczęściej stosowane skale w pomiarze pracoholizmu, koncentrując się na Wielowymiarowym Kwestionariuszu Oceny Pracoholizmu. W ostatniej części artykułu opisano wyniki badania własnego z wykorzystaniem tego kwestionariusza wśród pracowników WNEiZ UMK w Toruniu.

S ło w a k lu c z o w e: pracoholizm, aktywność twórcza

Klas yfikacja JEL: J24

\section{WPROWADZENIE}

Twórczość jest najbardziej skomplikowaną i zaawansowaną formą ludzkiego działania, która wiąże wszelkie możliwe rodzaje aktywności czło-

\footnotetext{
* Adres do korespondencji: Dawid Szostek, Uniwersytet Mikołaja Kopernika w Toruniu, Wydział Nauk Ekonomicznych i Zarządzania, Katedra Marketingu i Handlu, ul. Gagarina 13a, 87-100 Toruń, e-mail: Dawid.jan.szostek@gmail.com.
} 
wieka - por. [Popek, 2001, s. 13, 48]. Wynika z nieustannego dążenia ludzi do transcendencji oraz chęci przekraczania własnych ograniczeń i badania swoich możliwości. Jak pisze św. Jan Paweł II w swojej encyklice pt. „Laborem exercens” („O pracy ludzkiej”) z 1981 roku, „(...) człowiek, stworzony na obraz Boga, przez swoją pracę uczestniczy w dziele swego Stwórcy - i na miarę swoich ludzkich możliwości poniekąd dalej je rozwija i dopełnia, postępując wciąż naprzód w odsłanianiu ukrytych w całym stworzeniu zasobów i wartości” - por. [Encykliki..., 2007, s. 203].

Wydaje się, że współczesne czasy jak nigdy wcześniej umożliwiają człowiekowi rozwój wszelkich twórczych ambicji. Rozkwit nauki i techniki pozwala na przekraczanie kolejnych barier, które dotychczas zdawały się ograniczać człowieka w jego twórczych działaniach. Jednak aktywność ta nie jest pozbawiona mankamentów, jak choćby narastający pracoholizm wśród twórców.

Jednym $\mathrm{z}$ częściej przywoływanych $\mathrm{w}$ literaturze przedmiotu wyjaśnień tego zjawiska jest postrzeganie pracoholizmu jako formy uzależnienia. Należy zauważyć, że od początku XX wieku mamy do czynienia z intensyfikacją uzależnień oraz pojawianiem się nowych ich form. Są to coraz rzadziej uzależnienia od substancji (np. alkoholizm, narkomania), które z powodzeniem są zastępowane przez równie niebezpieczne uzależnienia od czynności (behawioralne). Coraz częściej mówi się o uzależnieniu od hazardu, Internetu, jedzenia, zakupów (zakupoholizm), seksu (erotomania), a nawet telefonu komórkowego, informacji czy operacji plastycznych. Dodatkowo w literaturze opisuje się takie przypadki, jak: tanoreksja (uzależnienie od opalania się, przede wszystkim w solarium), ortoreksja (od zdrowego jedzenia), bigoreksja (od smukłej i wysportowanej sylwetki), alkoreksja (zastępowanie jedzenia alkoholem w celu utrzymania szczupłej sylwetki) - por. [Ogińska-Bulik, 2010, s. 7-10]. Są to tylko wybrane przykłady patologicznych czynności człowieka o znamionach uzależnienia.

Pracoholizm jest szczególnie niebezpiecznym zjawiskiem. Jak zauważyła N. Ogińska-Bulik, ,'narkotyk' ten daje przyjemność, jest zawsze pod ręką i nic nie kosztuje, a co więcej, jego używanie jest aprobowane społecznie" - por. [Ogińska-Bulik, 2010, s. 35]. Niemożliwa jest też zupełna abstynencja, jak choćby w przypadku leczenia uzależnienia od alkoholu. Wydaje się, że w tym względzie szczególną grupą ryzyka są twórcy, których charakter pracy sprzyja rozwojowi pracoholizmu. Jest to choćby nienormowany czas pracy, ,zabieranie pracy do domu” (dom jest bardzo często głównym miejscem pracy dla twórców, stąd normą jest zacieranie granic pomiędzy czasem pracy i czasem prywatnym), wewnętrzna presja 
na jak najszybsze osiąganie rezultatów (np. awans zawodowy, ukończenie danego dzieła), wieloetatowość, a przez to - obciążanie/przeciążanie się obowiązkami, a przy tym (w tym przypadku groźny) brak monotonii i osiąganie satysfakcji i pożądanego stanu zaspokojenia już tylko dzięki samemu aktowi twórczemu (procesowi, a niekoniecznie jego wynikowi). Wszystko to sprzyja ,podświadomej pracy” twórców, nawet w chwilach pozornie wolnych od niej (np. natrętne myślenie o deadline'ach, „twórcze natchnienia" materializowane o każdej porze dnia i nocy). Jak pisze [Rudniański, 1981, s. 77]: „Mózg, w przeciwieństwie do mięśnia, nie przerywa pracy w chwili, gdy przerywamy ją świadomie. Stąd dążność do kontynuowania twórczej pracy, szczególnie jeśli nie napotyka się wyjątkowo dużych przeszkód. Twórcze myślenie bowiem odbywa się na dwóch poziomach: świadomym i podświadomym".

W związku z tym celem podjętym w artykule jest opisanie zjawiska pracoholizmu wśród osób, które zajmują się aktywnością twórczą. Jest to zagadnienie względnie słabo opisane w literaturze przedmiotu [Lipka et al., 2013], choć z pewnością bardzo interesujące. Co więcej, zjawisko to jest bardzo istotne zarówno z punktu widzenia twórcy-pracoholika, samej organizacji oraz gospodarki i społeczeństwa w skali makro (vide choćby negatywne skutki dla zdrowia pracoholika, niska efektywność jego pracy).

Autor oparł swoje rozważania na aktualnych źródłach wtórnych (książkowych i czasopiśmienniczych), a także na wynikach badania na temat skali pracoholizmu przeprowadzonego wśród pracowników naukowych WNEiZ UMK w Toruniu w 2015 roku.

\section{DEFINICJA AKTYWNOŚCI TWÓRCZEJ}

Kreatywność (traktowana w niniejszym opracowaniu synonimicznie z twórczością) jest główną przyczyną rozwoju społeczno-ekonomicznego. Jest to choćby źródło innowacyjności będącej motorem każdej gospodarki. Aktywność twórcza jest kojarzona przede wszystkim z pracą artystyczną, naukową i techniczną, jednak coraz częściej dostrzega się obecność cech twórczego działania w innych obszarach ludzkiej działalności (np. w prowadzeniu firmy). Ma to związek z tym, że w takich „nietypowo” twórczych obszarach uruchamiane są mechanizmy psychologiczne, obecne w działalności twórczej. Poza tym kreatywność to po prostu wykorzystywanie zdobytej wiedzy i jej przetwarzanie w oryginalne wartości, dobra i usługi-por. [Lipka et al., 2013, s. 13]. 
Takie postrzeganie twórczości oznacza, że jest ona cechą w zasadzie każdego człowieka, przy czym różni się jej natężenie i przejawy występowania. Jest to rozumienie twórczości sensu largo, którą można zdefiniować jako ,proces prowadzący do powstania nowego dzieła, uznanego przez pewną grupę ludzi jako zadowalające lub użyteczne w określonym czasie" [Popek, 2001, s. 13]. Z kolei [Rudniański, 1987, s. 12] pojęcie to rozumie jako „wewnętrzne (myślowe) lub zewnętrzne (przejawiające się w zachowaniu) rozwiązywanie każdego problemu, którego sposób rozwiązania lub rozwiązanie nie jest rozwiązującemu znane".

Wśród głównych cech aktywności twórczej należy wskazać na następujące [Lipka et al., 2013, s. 21-24]:

a) społecznie (powszechnie) uznana nowość,

b) społecznie (powszechnie) uznana wartość, przy czym aktywność twórcza może być wartością samą w sobie, jako że nie zawsze przynosi bezpośrednie rezultaty, a co więcej jest efektem długotrwałego nabywania wiedzy i doświadczenia w danej dziedzinie (a nie ,przebłysku geniuszu"),

c) związana z pracą wymagającą dużego zaangażowania i wysiłku (intelektualnego, psychicznego, a nawet fizycznego),

d) cechuje się dużą intensywnością motywacji (działanie długotrwałe, uporczywe),

e) towarzyszy jej doświadczenie ,przepływu” (ang. flow) - poczucie zatracenia się w działaniach i całkowite skoncentrowanie na aktywności, które wyróżnia się?:

- jasno określonym celem (na każdym etapie twórca wie, co robić, jaki ma być następny krok),

- otrzymywaniem informacji zwrotnej na temat rezultatów działania (ang. feedback),

- posiadaniem umiejętności adekwatnych do wyzwań,

- silnym skoncentrowaniem (do takiego stopnia, że działanie i świadomość stanowią jedność),

- unikaniem rozpraszających myśli i bodźców (fizyczne i/lub „mentalne” odizolowanie się),

- brakiem obawy popełnienia błędu (dla twórcy wszystko jest oczywiste i łatwe),

- zapominaniem o sobie (zanik samoświadomości),

1 Zjawisko to opisał [Csikszentmihalyi, 2005, s. 110-113]. 
- utratą poczucia czasu zegarowego (subiektywizm odczuwania czasu),

- doświadczeniem autoteliczności działania (aktywność twórcza, w tym naukowa bądź artystyczna, jest celem, wartością i nagrodą samą w sobie).

\section{POJECIE PRACOHOLIZMU, JEGO PRZYCZYNY, SYMPTOMY I SKUTKI}

Pojęcie pracoholizmu (ang. workaholism ${ }^{2}$ ) wzmiankował po raz pierwszy w 1968 roku W. E. Oates - profesor psychologii religii. W swoim artykule pt. „On Being a 'Workaholic”” (Bycie 'pracoholikiem'), opublikowanym na łamach „Pastoral Psychology” dokonał on porównania uzależnienia od pracy z alkoholizmem. Często stosowanymi w literaturze przedmiotu synonimami pracoholizmu są: uzależnienie od pracy, „,nerwica niedzielna”, szał pracy, miłość do pracy, bezgraniczne oddanie się pracy zawodowej, opętanie pracą [Bańka, 1996; Wachowiak, 2011; Szpitalak, 2012, s. 12].

Zjawisko to nie jest przez społeczeństwo oceniane w sposób jednoznaczny. Dla niektórych osób, a nawet badaczy, posiada ono cechy pozytywne i stąd utożsamia się je z pracowitością, pilnością, sumiennością, zaradnością czy nawet przedsiębiorczością. Wyrazem takiego podejścia jest choćby stosowanie następujących eufemizmów na pracoholizm: całkowite zaangażowanie, pełna dyspozycyjność/elastyczność, ponadnormatywna motywacja wewnętrzna, akceptacja elastycznych form zatrudnienia/elastycznych godzin pracy - por. [Wachowiak, 2011, s. 21].

W związku z tym do dziś nie wypracowano jednolitej definicji pracoholizmu. Nie ma też pełnej zgody co do uwarunkowań oraz przejawów tego zjawiska. Pewne jest to, że pracoholizmu nie można odnosić wyłącznie do zajęć o charakterze zawodowym. W zasadzie każda aktywność człowieka nakierowana na osiągnięcie określonych celów, traktowana zadaniowo i podparta wewnętrznym przymusem jej podejmowania może mieć znamiona pracoholizmu (np. nauka/studiowanie, prowadzenie domu).

Poza tym już dawno obalono mit, że zjawisko to dotyczy tylko osób na stanowiskach kierowniczych (praca umysłowa). Wyniki badań potwierdza-

2 Etymologicznie termin ten wywodzi się z kompilacji dwóch słów: work (ang. praca) oraz holizm (od greckiego słowa holos, tj. „,cały”). W dosłownym thumaczeniu oznacza zatem ,cały pracą”. 
ją, że uzależnienie od pracy może dotykać również osoby pracujące fizycznie, na stanowiskach wykonawczych, zatem rodzaj zawodu nie warunkuje występowania tego zjawiska - por. [Golińska, 2008, s. 53].

Wojdyło [2010, s. 18] rozumie zatem pracoholizm jako, ,zjawisko, polegające na obsesyjnym zaangażowaniu w pracę, które cechuje samodzielne narzucanie sobie przez jednostkę bardzo wysokich wymagań, niezdolność do regulowania przyzwyczajeń w miejscu pracy oraz nadmiar pracy (poświęcanie się pracy), powiązany z rezygnacją z większości innego rodzaju aktywności życiowych, z konsekwencjami zaburzeń w sferze funkcjonowania podmiotowego oraz relacji interpersonalnych".

Źródłem powstawania pracoholizmu może być sam człowiek oraz jego środowisko, i to zarówno w skali mikro (np. rodzina, miejsce pracy), jak i makro (np. gospodarka, społeczeństwo). Wśród najczęściej wskazywanych teorii wyjaśniających pracoholizm można wskazać na trzy następujące ${ }^{3}$ :

1) niekontrolowane uzależnienie,

2) powielanie utrwalonych, patologicznych zachowań z dzieciństwa,

3) skutek osobowości anankastycznej (obsesyjno-kompulsyjnej).

Ad 1. Wiedza o uzależnieniach jest młodą dziedziną medycyny, jako że zaczęła się rozwijać w USA, w latach 40. XX wieku i to w odniesieniu do alkoholizmu. W tym rozumieniu pracoholizm cechuje się [Ogińska-Bulik, 2010, s. 10-11; Wachowiak, 2011, s. 40-42; Szpitalak, 2012, s. 14-16; Lipka er al., 2013, s. 27-30]:

- wewnętrznym przymusem podejmowania określonych czynności,

- trudnościami w kontrolowaniu określonych zachowań, w tym niepowodzeniami w próbach „odstawienia”/ograniczenia pracy,

- redukowaniem lęku i strachu, przy czym jest to trudne/niemożliwe do osiągnięcia poprzez inne czynności,

- psychosomatycznymi konsekwencjami redukowania ilości bądź odstawienia pracy,

- rosnącym poziomem tolerancji na pracę,

- zaniedbywaniem bliskich, przyjaciół, innych czynności i przyjemności,

- kontynuowaniem tych praktyk pomimo świadomości konsekwencji dla zdrowia i psychiki pracoholika.

3 Pracoholizm jest także często wyjaśniany jako skutek przeciążenia pracą (ang. work overload) oraz sposób na ucieczkę od problemów osobistych. 
Ad 2. Teoria wyjaśniająca pracoholizm jako powielanie utrwalonych, nieprawidłowych zachowań z dzieciństwa wskazuje, że zjawisko to ma charakter nabyty. Przyczyną jego powstawania jest dysfunkcyjna rodzina, która nie zaspokaja u dziecka potrzeby miłości, bezpieczeństwa czy pewności, natomiast wpaja dzieciom konieczność nieustannego kontrolowania sytuacji oraz bycia zajętym. Dorastanie w takiej rodzinie zostawia na psychice dziecka niezatarte ślady, stąd w terapii pracoholizmu mówi się często o syndromie Dorosłych Dzieci Pracoholików (DDP).

Ad 3. Do głównych cech osobowości anankastycznej należą: sztywność przekonań, skrupulatność, upór, perfekcjonizm, pedanteria, brak asertywności, wytrwałość, pracowitość, ambicja, sumienność, trudności w podejmowaniu decyzji - por. [Szpitalak, 2012, s. 26]; [Lipka et al., 2013, s. 60]. Zgodnie z tą teorią pracoholizm ma swoje źródło w samym człowieku (w jego osobowości; jest to warunek niezbędny), natomiast jego wyzwalanie i intensyfikacja mogą być pochodną otaczających jednostkę uwarunkowań (np. społecznych, organizacyjnych, etc.).

Najczęściej wskazywane w literaturze objawy pracoholizmu, na których bazuje większość skal do pomiaru tego zjawiska (por. kolejna część artykułu), można podzielić na 9 następujących grup [Lipka et al., 2013, s. 104-110; Bańka, 1996, s. 40; Wachowiak, 2011, s. 27, 36, 38; Szpitalak, 2012, s. 46-59; Kozak, 2009, s. 109].

1) przymus pracy (ciągłe myślenie o niej; utrata kontroli nad czasem pracy; presja wewnętrzna na pracę; ulga przy jej wykonywaniu; etc.);

2) standardy pracy (narzucanie sobie i innym nierealistycznych wymogów; brak umiejętności delegowania zadań; porównywanie się z innymi; ciągły pośpiech; perfekcjonizm; etc.);

3) kategoria poznawcza (praca sensem życia i podstawową kategorią poznawania świata; wykonywanie wszystkich działań, nawet pozazawodowych, z nastawieniem na cel/rezultaty, etc.);

4) rezygnacja $z$ innych aktywności niż zawodowa (każda aktywność poza pracą to kradzież czasu, jego marnotrawienie; rezygnacja z wypoczynku, relaksu; wycofanie z życia rodziny, społeczeństwa; etc.);

5) zaburzenia relacyjne (rosnący egoizm; lekceważenie potrzeb innych; dystansowanie się od bliskich; zapominanie o ważnych uroczystościach; wpajanie dzieciom, że praca jest najważniejsza; samotność, etc.);

6) problemy zdrowotne (chroniczne wyczerpanie, przemęczenie, stres, lęk; dolegliwości somatyczne i psychiczne; brak czasu na potrzeby fizjologiczne; etc.); 
7) działanie dezadaptacyjne (szukanie pocieszenia w pracy; racjonalizowanie patologicznej relacji do pracy pomimo dolegliwości z tym związanych - np. mam kredyt, muszę pracować dla dobra dzieci, etc.);

8) niezdolność do abstynencji (sporządzanie list obowiązków; praca to warunek powrotu do równowagi emocjonalnej; lęk przed czasem wolnym, etc.);

9) poczucie własnej wartości (,przeglądanie się” w innych; praca to wyznacznik własnej tożsamości i wartości jako osoby; lęk przed lenistwem; dążenie do uznania w oczach innych, etc.).

Kończąc rozważania na temat pracoholizmu, nie sposób nie wspomnieć o jego skutkach. Z pewnością można się łatwo domyślić, że dominujący charakter mają konsekwencje negatywne. Co prawda można przypuszczać, że pracoholizm oznacza także poprawę stanu materialnego pracoholika i jego bliskich, rozwój kariery czy wysokie zaangażowanie na rzecz organizacji. Są to jednak skutki krótkotrwałe i do tego skutecznie dyskontowane przez ogrom skutków negatywnych, które można ująć z perspektywy:

1) pracoholika i jego otoczenia:

- rezygnacja z życia rodzinnego/towarzyskiego, a przez to - negatywne konsekwencje dla relacji, dzieci (np. rozwody, syndrom DDP u dzieci pracoholika),

- skrajne i przewlekłe wyczerpanie psychosomatyczne,

- choroby psychosomatyczne (wrzody, wieńcówka, nerwice, duszności, bóle stawowe, problemy z trawieniem, etc.),

- popadanie w nałogi (alkohol, narkotyki, leki),

- przyspieszona śmierć (pierwszy przypadek śmierci z przepracowania opisano w Japonii w 1968 r.; jap. karoshi);

2) organizacji:

- mniejsza kreatywność (dominuje myślenie przystosowawcze); efektowność zamiast efektywności (głównie jako konsekwencja „rozsmakowywania" się w czynnościach i perfekcjonizmu),

- konflikty z innymi pracownikami,

- utrata motywacji do działania na rzecz wewnętrznego przymusu pracy,

- większa absencja, także wskutek chorób, depresji, wyczerpania,

- wyższy wskaźnik braków; większe ryzyko działania;

3) całej gospodarki:

- koszty pracoholizmu i usuwania/łagodzenia jego konsekwencji ponosi całe społeczeństwo, 
- niższa aktywność zawodowa pracoholików,

- intensyfikacja wielu patologii związanych z rozwojem pracoholizmu (np. narkomania, alkoholizm).

\section{NAJCZESŚCIEJ STOSOWANE SKALE W POMIARZE PRACOHOLIZMU}

W badaniach pracoholizmu najczęściej wykorzystywane są cztery następujące skale pomiarowe ${ }^{4}$ :

- Work-BAT - Workaholism Battery (J. Spence i A. Robbins, 1992),

- WART - Work Addiction Risk Test (B. E. Robinson i B. Philips, 1995),

- SZAP - Skala Zaabsorbowania Pracą (L. Golińska i M. Pasik, 2008),

- skala P. Mudracka i T. Naughton (2001).

WORK-BAT

J. Spence i A. Robbins są autorkami pierwszej skali do pomiaru pracoholizmu. Skala ta zawiera 25 stwierdzeń opartych na trzech wymiarach:

- zaangażowanie w pracę (ang. work involvement), np.: „Czuję się znudzony i niespokojny na wakacjach, gdy nie mam do zrobienia niczego produktywnego";

- wewnętrzny przymus pracy (ang. feeling driver to work), np.: „Często czuję, gdy coś wewnątrz motywuje mnie do tego, by ciężko pracować";

- zadowolenie z pracy (ang. enjoyment of work), np.: „Moja praca jest tak interesująca, że często wydaje się jakby nie była pracą".

Uzyskane dane pozwalają na zakwalifikowanie respondentów do trzech typów pracoholików:

- uzależnieni pracoholicy (wewnętrzny przymus, zaangażowanie, brak zadowolenia);

- entuzjastyczni pracoholicy (wewnętrzny przymus, zaangażowanie, zadowolenie);

- entuzjaści pracy (brak wewnętrznego przymusu, zaangażowanie, zadowolenie).

4 Opracowano na podstawie: [Golińska, 2008, s. 54-67]. 
Późniejsze badania nad tą skalą podważyły jej rzetelność, dowodząc, że jedynie wewnętrzny przymus pracy oraz zadowolenie z niej statystycznie istotnie różnicują badane zjawisko. Przyczyną mankamentów tej skali może być fakt, że powstała ona głównie na podstawie wyników badań przeprowadzonych wśród studentów pierwszego roku psychologii - por. [Szpitalak, 2012, s. 73].

\section{WART}

Jest to chyba najbardziej popularna skala w badaniach pracoholizmu. Zbudowana jest $\mathrm{z}$ pięciu wymiarów, które statycznie istotnie różnicują badane zjawisko (co potwierdzono w stosownych badaniach empirycznych): przeciążenie pracą (ang. overdoing), poczucie własnej wartości (ang. self-worth), kontrola/perfekcjonizm (ang. control/perfectionism), zaniedbywanie bliskich związków (ang. intimacy), umysłowe zaabsorbowanie/odniesienia do przyszłości (ang. mental preoccupation/future reference).

Na grunt polski skalę tę zaadaptowała K. Wojdyło (2005). Zaadaptowana skala składa się z 25 sformułowań, tworzących również pięć wymiarów:

- obsesja/kompulsja (np. „Trudno jest mi się odprężyć, gdy nie pracuję"),

- emocjonalne pobudzenie/perfekcjonizm (np. „Tracę panowanie nad sobą, jeśli sprawy nie idą po mojej myśli"),

- przeciążenie pracą (np. „Wydaje się, że śpieszę się i ścigam z czasem"),

- orientacja na wynik (np. „Bardziej interesuje mnie wynik mojej pracy niż sam proces"),

- poczucie własnej wartości (np. „Zapominam, ignoruję lub lekceważę urodziny, zjazdy, rocznice czy wakacje").

Należy zauważyć, że skala WART posiada istotne uchybienia. Po pierwsze wiele ze sformułowań koncentruje się na pośpiechu czy wykonywaniu kilku zadań jednocześnie, co niekoniecznie musi oznaczać pracoholizm, ale może być przejawem stylu pracowania bądź kultury danej organizacji opartej na presji na czas czy obciążaniu pracowników zadaniami. Drugi zarzut odnosi się do wymiaru ,poczucie własnej wartości” - składają się na niego cztery sformułowania, ale tak naprawdę tylko jedno odnosi się do istoty tego zjawiska (por. choćby wyżej przytoczone sformułowanie). Po trzecie autorzy skali wychodzą z niepotwierdzonego empirycznie założenia, że pracoholizm wiąże się z niską samooceną. 


\section{SZAP}

Już sama etymologia nazwy tej skali - skala zaabsorbowania pracą (łac. absorbo - odsysam) - wskazuje, że pracoholizm jest definiowany przede wszystkim przez pryzmat ilości czasu poświęcanego na wykonywanie pracy. Przyznają to same autorki, które czas poświęcany pracy wykorzystały jako główne kryterium trafności opracowanej skali - por. [Golińska, 2008, s. 62]. Tymczasem, jak już wskazano, duża ilość czasu przeznaczana na wykonywanie pracy wcale nie musi oznaczać, że dana osoba jest pracoholikiem - por. [Wachowiak, 2011, s. 25].

Niemniej jednak opracowaniu tej skali towarzyszyło założenie, że pracoholizm jest uzależnieniem, zatem sformułowania składające się na $\mathrm{SZAP}^{5}$ (łącznie 38) muszą odzwierciedlać siedem podstawowych wymiarów uzależnienia:

- wewnętrzny przymus używania (w tym przypadku - wykonywania czynności),

- rosnący poziom tolerancji (coraz większe „dawki” pracy oraz jej intensywność potrzebne do tego, by uzyskać ten sam poziom „równowagi"),

- niepowodzenia w próbach „odstawienia” pracy,

- cierpienie psychosomatyczne w przypadku prób odstawienia,

- sztywny schemat zachowań (co do przebiegu wykonywania aktywności),

- racjonalizacja podejmowanych aktywności (często pomimo świadomości ich wyniszczającego charakteru),

- ponoszenie kosztów zdrowotnych (fizycznych i psychicznych) zachowania.

\section{SKALA P. MUDRACKA I T. NAUGHTON}

W skali tej pracoholizm jest traktowany jako tendencja behawioralna. Autorom towarzyszyło przekonanie, że wcześniej konstruowane skale opierały się na takich predyktorach zjawiska pracoholizmu, jak intensywność

5 Np. „Tylko gdy intensywnie pracuję czuję się człowiekiem w pełni wartościowym”, „Często mam ochotę wpaść wieczorem do pracy”, „Uważam, że pracowitość jest jedną z najważniejszych cech człowieka". 
pracy, jej czasochłonność czy rytm, natomiast zapominano o następujących czynnikach:

- stopień „wykraczania” pracownika poza oczekiwania pracodawcy,

- myślenie o pracy w czasie wolnym,

- wybieranie pracy do spędzania czasu wolnego.

W celu wyeliminowania w pomiarze pracoholizmu subiektywnych odczuć osoby badanej, pomiar zjawiska powinien opierać się na identyfikowaniu takich zachowań związanych z pracą, które wskazują na ich fakultatywność i nieoczekiwanie przez pracodawcę. Skoncentrowano się zatem na dwóch wymiarach: myślenie o tym, jak ulepszyć wykonywaną pracę oraz ocena czasu i energii poświęcanej na kontrolowanie pracy innych. Osoba badana ocenia zatem (w skali od 1 - wcale/nieznacznie do 5 - bardzo dużo), ile czasu i energii poświęca m.in. na myślenie o sposobach bycia bardziej produktywnym czy sprawdzanie poprawności pracy innych osób.

Poza opisanymi skalami pomiarowymi, w praktycznych badaniach pracoholizmu stosowane są także inne. Jest to choćby Test Ryzyka Uzależnienia od Pracy autorstwa J. Mellibrudy $(1997)^{6}$. Co prawda sam autor dostrzega, że nie jest to $\mathrm{w}$ pełni profesjonalny instrument $\mathrm{w}$ diagnostyce pracoholizmu, jednak może być przydatny na etapie wstępnej oceny, czy mamy do czynienia ze „zdrowym” podejściem do pracy. Skala zawiera 15 sformułowań ${ }^{7}$, do których należy się odnieść na skali od 1 (nigdy nie jest prawdziwe), poprzez 2 (rzadko jest prawdziwe) i 3 (często jest prawdziwe) aż do 4 (zawsze jest prawdziwe).

W badaniach przeprowadzonych przez autora nie zastosowano żadnej z wymienionych skal pomiarowych, ale tzw. Wielowymiarowy Kwestionariusz Oceny Pracoholizmu (WKOP) autorstwa M. Szpitalak (2012). Powody tej decyzji opisano w kolejnej części artykułu.

\section{WIELOWYMIAROWY KWESTIONARIUSZ OCENY PRACOHOLIZMU (WKOP)}

Autorem WKOP jest M. Szpitalak, która zdecydowała się na jego opracowanie w związku z zaobserwowanymi i potwierdzanymi przez polskich

6 Opracowanie własne na podstawie: [Ogińska-Bulik, 2010, s. 42].

7 Przykładowo: „Jestem stale zajęty i muszę pilnować wielu spraw”, „Robię dwie lub trze rzeczy naraz, np. jem i robię notatki w czasie rozmowy telefonicznej”, „Źle się czuję, gdy popełniam nawet niewielkie błędy". 
i zagranicznych autorów mankamentami obecnie wykorzystywanych instrumentów. Główną przesłanką do skonstruowania tej skali było to, że „pracoholizm jest zjawiskiem w znacznie większym stopniu wielowymiarowym niż znajduje to odbicie w istniejących narzędziach" [Szpitalak, 2012, s. 79]. W związku z tym, w przekonaniu Autorki, pracoholizm winien być traktowany raczej jako zespół współwystępujących ze sobą objawów niż jako jedna, konkretna cecha - por. [Szpitalak, 2012, s. 131].

Poza tym autorzy najczęściej stosowanych instrumentów odmiennie pojmowali to, czym jest pracoholizm, co znajdowało odbicie w tych instrumentach. Uwzględniano w nich tylko wybrane, tendencyjne spojrzenie na to, czym jest pracoholizm i jakie są jego źródła.

W związku z tym WKOP nie bazuje na jakiejś konkretnej klasyfikacji pracoholików bądź teorii pracoholizmu, ale uwzględnia wszystkie z nich, zarówno te, które traktują zjawisko jako uzależnienie, zaburzenie osobowości czy nawyków, jak i te, które wiążą pracoholizm z aspektami pozytywnymi (np. entuzjazm, sumienność) - por. [Szpitalak, 2012, s. 80].

W konsekwencji instrument obejmuje aż 94 itemy, które można podzielić na 13 odrębnych skal/grup symptomów pracoholizmu:

1) praca jako wartość (15 itemów) - aktywność (głównie zawodowa) traktowana jest jako najważniejsza w życiu człowieka, jest punktem odniesienia dla otaczającej rzeczywistości;

2) sumienność (11) - obowiązkowość; odpowiedzialność; przykładność;

3) upośledzenie czynności alternatywnych (8) - problemy psychofizyczne związane $\mathrm{z}$ wyczerpaniem organizmu; traktowanie pozazawodowych obowiązków jako marnowanie czasu;

4) stres, lęk (9) - brak pewności siebie; permanentna obawa o „bycie w tyle" z obowiązkami; ciągłe myślenie o pracy; niemożność zrelaksowania się;

5) używki (6) - popadanie w inne używki, które „pomagają” zapomnieć o problemach (alkohol, narkotyki);

6) antydelegowanie (6) - brak umiejętności delegowania zadań na inne osoby;

7) zaburzone relacje społeczne (6) - zaniedbywanie życia prywatnego, potrzeb innych osób (przyjaciół, rodziny, etc.);

8) entuzjazm (4) - aktywność (głównie zawodowa) jest źródłem największe satysfakcji;

9) destrukcyjny perfekcjonizm (4) - zbytnia koncentracja na detalach kosztem efektywności i skuteczności działania; 
10) potrzeba przewidywalności (8) - przesadne planowanie; traktowanie każdej aktywności (nawet wypoczynku) zadaniowo; potrzeba kontroli otoczenia;

11) nadobowiązkowość (5) - bycie aktywnym (głównie zawodowo) nawet w sytuacji, gdy okoliczności tego nie wymagają; wykraczanie poza oczekiwaną aktywność;

12) absorpcja (5) - zatracanie się w aktywności (głównie zawodowej); doświadczanie poczucia przepływu (flow);

13) przymus pracy (6) - praca jako obsesja-kompulsja.

\section{METODYKA BADANIA ORAZ OMÓWIENIE JEGO WYNIKÓW ${ }^{8}$}

Pomiar z wykorzystaniem WKOP przeprowadzono w marcu i kwietniu 2015 roku metodą ankiety internetowej online ${ }^{9}$ oraz ankiety ogólnej wśród pracowników naukowych, dydaktycznych oraz naukowo-dydaktycznych WNEiZ UMK w Toruniu. W przypadku ankiety ogólnej kwestionariusz był dostępny w widocznym miejscu w wydziałowej portierni. Po tygodniu od rozesłania wiadomości z prośbą o udział w badaniu dokonano wysyłki przypominającej.

Łącznie otrzymano 26 poprawnie wypełnionych kwestionariuszy, przy czym 22 drogą elektroniczną. W badaniu wzięło udział 12 kobiet $(\mathrm{K})$ i 14 mężczyzn (M); 8 osób (3 K) było w wieku 26-35 lat, 12 (6 K) miało od 36-45 lat, 1 osoba $(\mathrm{K})-46-55$ lat, 4 osoby - 56-65 lat (2 K), a 1 respondent (M) miał 66-75 lat. Jeśli chodzi o posiadany tytuł naukowy/zawodowy, w badaniu wzięło udział 6 magistrów (w tym jedna osoba była dodatkowo inżynierem), 14 doktorów, 1 doktor habilitowany, 4 profesorów nadzwyczajnych i 1 profesor zwyczajny. Najwięcej, tj. 22 osoby, piasto-

8 Szczególne podziękowania za możliwość zrealizowania badania składam na ręce Dziekana WNEiZ UMK w Toruniu, prof. dr. hab. Józefa Stawickiego. Dziękuję także wszystkim pracownikom tegoż Wydziału, którzy w jakiejkolwiek formie wspomogli mnie w moich wysiłkach badawczych (w tym przede wszystkim dr Iwonie Escher).

9 Kwestionariusz ankiety jest dostępny pod adresem: https://docs.google.com/ forms/d/1iTLKJe3NN2wHu4Ggv8wkXPCFRirn3wrJflf2S9v-MQM/viewform. W instrumencie opracowanym przez M. Szpitalak dokonano jedynie poprawek natury semantycznej w 20 sformułowaniach, nadając im bardziej jednoznaczne brzmienie, a także opracowano własną metryczkę, uwzględniającą specyfikę badanej populacji. 
wały stanowisko naukowo-dydaktyczne, 3 osoby - wyłącznie naukowe, a 1 osoba - wyłącznie dydaktyczne.

Zbiorcze wyniki z pomiaru zawarto w tabeli $\mathrm{nr} 1$. Każdego respondenta zakwalifikowano do odpowiedniej kategorii ze względu na natężenie występowania danej grupy objawów pracoholizmu (od bardzo niskiego natężenia do bardzo wysokiego natężenia). Należy podkreślić, że nie stwierdzono, aby istotny wpływ na tę kwalifikację miały płeć czy wiek danej osoby, a także rodzaj zajmowanego stanowiska pracy bądź posiadany tytuł/ stopień naukowy/zawodowy.

Tabela 1. Zbiorcze wyniki pomiaru dla poszczególnych grup symptomów pracoholizmu

\begin{tabular}{|c|c|c|c|c|c|c|c|c|c|c|c|}
\hline \multirow{3}{*}{ GRUPY SYMPTOMÓW } & \multicolumn{7}{|c|}{ Natężenie występowania objawów wg norm dla WKOP } & \multirow{3}{*}{$\begin{array}{c}\% d l a \\
Z W, W i \\
B W\end{array}$} & \multirow{3}{*}{$\begin{array}{c}\% d l a W i \\
B W\end{array}$} & \multirow{3}{*}{$\begin{array}{c}\% \text { dla } B N \\
\text { i } N\end{array}$} & \multirow{3}{*}{$\begin{array}{c}\% \text { dla } B N \\
\text { Ni } Z N\end{array}$} \\
\hline & $\begin{array}{l}\text { Bardzo } \\
\text { niskie }\end{array}$ & Niskie & Zaniżone & $\begin{array}{c}\mathrm{W} \\
\text { normie }\end{array}$ & Zawyżone & Wysokie & $\begin{array}{c}\text { Bardzo } \\
\text { wysokie }\end{array}$ & & & & \\
\hline & $B N$ & $N$ & $Z N$ & $W N$ & $Z W$ & $W$ & $B W$ & & & & \\
\hline Sumienność & 0 & 0 & 0 & 5 & 4 & 13 & 4 & $80,8 \%$ & $65,4 \%$ & $0,0 \%$ & $0,0 \%$ \\
\hline $\begin{array}{l}\text { Upośledzenie czynności } \\
\text { alternatywnych }\end{array}$ & 0 & 2 & 3 & 5 & 6 & 6 & 4 & $61,5 \%$ & $38,5 \%$ & $7,7 \%$ & $19,2 \%$ \\
\hline Entuzjazm & 0 & 6 & 2 & 5 & 5 & 7 & 1 & $50,0 \%$ & $30,8 \%$ & $23,1 \%$ & $30,8 \%$ \\
\hline Stres i lęk & 5 & 4 & 2 & 3 & 2 & 3 & 7 & $46,2 \%$ & $38,5 \%$ & $34,6 \%$ & $42,3 \%$ \\
\hline Nadobowiązkowość & 0 & 2 & 5 & 9 & 7 & 3 & 0 & $38,5 \%$ & $11,5 \%$ & $7,7 \%$ & $26,9 \%$ \\
\hline Wartość & 1 & 0 & 4 & 13 & 3 & 5 & 0 & $30,8 \%$ & $19,2 \%$ & $3,8 \%$ & $19,2 \%$ \\
\hline Zaburzone relacje społeczne & 0 & 4 & 4 & 10 & 3 & 4 & 1 & $30,8 \%$ & $19,2 \%$ & $15,4 \%$ & $30,8 \%$ \\
\hline Potrzeba przewidywalności & 0 & 2 & 8 & 9 & 2 & 4 & 1 & $26,9 \%$ & $19,2 \%$ & $7,7 \%$ & $38,5 \%$ \\
\hline Przymus pracy & 2 & 5 & 4 & 8 & 3 & 4 & 0 & $26,9 \%$ & $15,4 \%$ & $26,9 \%$ & $42,3 \%$ \\
\hline \begin{tabular}{|l} 
Destrukcyjny perfekcjonizm \\
\end{tabular} & 1 & 7 & 4 & 8 & 2 & 2 & 2 & $23,1 \%$ & $15,4 \%$ & $30,8 \%$ & $46,2 \%$ \\
\hline \begin{tabular}{|l} 
Antydelegowanie \\
\end{tabular} & 2 & 6 & 7 & 6 & 2 & $\frac{L}{1}$ & 2 & $19,2 \%$ & $11,5 \%$ & $30,8 \%$ & $57,7 \%$ \\
\hline Absorpcja & 0 & 6 & 6 & 9 & 1 & 4 & 0 & $19,2 \%$ & $15,4 \%$ & $23,1 \%$ & $46,2 \%$ \\
\hline Używki & 0 & 8 & 9 & 7 & 2 & 0 & 0 & $7,7 \%$ & $0,0 \%$ & $30,8 \%$ & $65,4 \%$ \\
\hline Liczba osobowskazań & 11 & 52 & 58 & 97 & 42 & 56 & 22 & & & & \\
\hline \% osobowskazań & $3,3 \%$ & $15,4 \%$ & $17,2 \%$ & $28,7 \%$ & $12,4 \%$ & $16,6 \%$ & $6,5 \%$ & & & & \\
\hline
\end{tabular}

Źródło: opracowanie własne na podstawie wyników badania.

Ponad $80 \%$ respondentów (21 osób) można zaklasyfikować jako osoby sumienne, a połowa $\mathrm{z}$ nich wykazała duży entuzjazm pracy (suma liczby osób zakwalifikowanych do normy zawyżonej, wysokiej i bardzo wysokiej). Są to pozytywne symptomy, często utożsamiane z pracoholizmem, choć wcale nie muszą oznaczać jego występowania.

W przypadku $61,5 \%$ respondentów (16 osób), w mniejszym bądź większym stopniu, zdiagnozowano upośledzenie czynności alternatywnych, a 8 osób posiadało zaburzone relacje społeczne. Prawie połowa $\mathrm{z}$ nich (12 osób) doświadczała różnych przejawów stresu i lęku związanego z wykonywaną pracą, a 10 osób zakwalifikowano jako nadobowiązkowe.

Przymusu pracy doświadczała niewiele ponad $1 / 4 \mathrm{z}$ nich (7 osób), a 6 osób przejawiało destrukcyjny perfekcjonizm. W najmniejszym natężeniu wystąpiły objawy związane ze stosowaniem używek. Jedynie 2 osoby zakwalifikowano do kategorii ,zawyżone natężenie zjawiska”. 
Sumując liczbę osobowskazań w poszczególnych kategoriach natężenia występowania danej grupy objawów, należy wskazać na normalność rozkładu tego zjawiska. Mniej więcej tyle samo osobowskazań odnotowano dla sumy kategorii BN, N i ZN, co dla sumy kategorii ZW, W i BW (po niespełna $36 \%$ osobowskazań). W przypadku porównania sumy kategorii $\mathrm{BN}$ i $\mathrm{N}$ oraz $\mathrm{W}$ i BW widoczna jest niewielka przewaga drugiej z par tych kategorii. Wyniki w normie odnotowano dla niespełna 29\% osobowskazań. Niemniej jednak nie oznacza to, że wyniki te napawają optymizmem i nie występuje problem większej tendencji do pracoholizmu w przypadku grupy twórców (w tym przypadku - pracowników nauki). Wręcz przeciwnie - w zależności od rodzaju objawów, zjawisko to występowało w badanej grupie $\mathrm{z}$ różnym natężeniem.

\section{PODSUMOWANIE}

Autor jest świadomy, że zrealizowane badanie ma charakter eksploracyjny i posiada wiele mankamentów, jak choćby zbyt mała liczba respondentów, by dokonywać statystycznie istotnego wnioskowania. Konieczne byłoby także porównanie wyników pomiaru w grupie twórców z podobnymi wynikami dla innych rodzajów profesji.

Poza tym w badaniu zjawiska pracoholizmu należy odchodzić od metod ilościowych ku metodom jakościowym, jak indywidualne i grupowe wywiady pogłębione czy obserwacje. Wie to większość studentów pierwszego roku zarządzania, których program studiów obejmuje kurs badań marketingowych ${ }^{10}$. Pracoholizm jest przecież zjawiskiem bardzo złożonym oraz stanowi swego rodzaju tabu, przez co trudno uchwycić to zjawisko w pomiarze metodami ilościowymi, a taką tendencję można obserwować wśród większości badaczy pracoholizmu.

Niemniej jednak zjawisko pracoholizmu wśród twórców (w tym przypadku - przedstawicieli świata nauki) występuje i to w stopniu względnie znaczącym oraz wieloaspektowym, jak pozwalają zauważyć zaprezentowane wyniki badania. W opinii autora artykuł może i powinien stanowić przyczynek do dalszej dyskusji oraz bardziej pogłębionych analiz.

10 Autor wyraża to przekonanie jako osoba prowadząca takie zajęcia. 


\section{BIBLIOGRAFIA}

Bańka A. (1996), Psychopatologia pracy, Wydawnictwo Gemini s. c., Poznań. Csikszentmihalyi M. (2005), Przepływ. Psychologia optymalnego doświadczenia, Moderator, Taszów.

Encykliki Ojca Świętego Jana Pawła II (2007), Wydawnictwo Znak, Kraków.

Golińska L. (2008), Pracoholizm. Uzależnienie czy pasja?, Difin, Warszawa.

Kozak S. (2009), Patologie w środowisku pracy. Zapobieganie i leczenie, Difin, Warszawa.

Lipka A., Waszczak S., Winnicka-Wejs A. (2013), Aktywność twórcza a pracoholizm. Jak utrzymać kapitał kreatywności pracowników?, Difin, Warszawa.

Ogińska-Bulik N. (2010), Uzależnienie od czynności. Mit czy rzeczywistość, Difin, Warszawa.

Popek S., (2001), Człowiek jako jednostka twórcza, Wydawnictwo UMCS, Lublin. Rudniański J. (1981), Homo cigitans, Wiedza Powszechna, Warszawa.

Szpitalak M. (2012), Wielowymiarowy Kwestionariusz Oceny Pracoholizmu, Wydawnictwo Uniwersytetu Jagiellońskiego, Kraków.

Wachowiak J. (2011), Dysfunkcyjne zachowania pracowników, Difin, Warszawa.

Wojdyło K. (2010), Pracoholizm. Perspektywa poznawcza, Difin, Warszawa.

\section{WORKAHOLISM IN HUMAN CREATIVE ACTIVITY ON THE EXAMPLE OF ACADEMICS}

Summary: The article discusses the phenomenon of workaholism among people involved in creative activities (including science). The first part defines creative activity, then it describes the causes, manifestations and consequences of workaholism. The next section presents the most commonly used scales to measure workaholism, focusing on the Multidimensional Workaholism Assessment Questionnaire (MWAQ). In the last part the author describes the results of his own research using MWAQ among employees of the Faculty of Economic Sciences and Management of Nicolaus Copernicus University in Toruń.

Keywords: workaholism, creative activity 